\title{
Kinetics of the HCG-induced Steroidogenic Response of the Human Testis. III. Studies in Children of the Plasma Levels of Testosterone and HCG: Rationale for Testicular Stimulation Test
}

\author{
MAGUELONE G. FOREST, ${ }^{(55)}$ M.D., Ph.D., MICHEL DAVID, M.D., ANNICK LECOQ, M. JEUNE, M.D., \\ AND JEAN BERTRANS, M.D \\ Unité INSERM U 34 Hopital Debrousse /M. G. F., A. L., J. B.], and the Pediatric Clinic, Hopital Debrousse /M. D. \\ M. J.J. Lion, France
}

\begin{abstract}
Summary
Little information is available regarding the time, rhythm, number, and appropriate dosage of human chorionic gonadotropin (HCG) for adequate testing of testicular function in human. The time course of the effect of two, three, or seven HCG injections at intervals of one, five, and two days, respectively, on the plasma levels of testosterone was studied in 11 boys. The first injection induced a progressive and modest rise of $T$. The second given one day later had little additive effect, maximal values being seen 72 to $120 \mathrm{hr}$ later. In the prepubertal boys to whom several HCG injections were given, testosterone levels reached comparable levels after four injections every five days or seven injections every other day. Although the number of subjects studied was relatively small, these results give some rational basis for the following HCG test: two or four injections at four-day intervals.
\end{abstract}

\section{Speculation}

In adult men or rats, human chorionic gonadotropin induces a rapid increase in testosterone biosynthesis, followed by a steroidogenic desensitization phenomenon and a trophic effect. The recruitment of new functioning Leydig cells probably occurs parallel to the steroidogenic refractoriness of the cells when gonadotropic stimulation reaches a certain level.

During pubertal development, luteinizing hormone also induces the differentiation of existing nonsteroidogenic interstitial cells into Leydig cells. Meanwhile, circulating levels of testosterone progressively increase. Assuming that endogenous luteinizing hormone has the same actions as human chorionic gonadotropin, it is speculated that if a possible induction of refractoriness of the Leydig cells is present at this stage, it might "modulate" the testicular response to the increasing levels of luteinizing hormone and partially explain the relatively slow achievement of a fully active testicular secretion in humans.

The stimulatory effect of gonadotropin on testicular endocrine function is well established $(4,23,24,26,27,34,47)$. Early studies have shown that in children, like in adults, the parenteral administration of human chorionic gonadotropin (HCG) is followed by an increase in the urinary excretion $(7,22,25,51)$ or the plasma levels $(13,27)$ of testosterone.

In the last decade, numerous studies attempting to test testicular function in children in normal or pathologic conditions appeared in the literature $(1-3,5,6,8,10,11,14,15,29-32,35,36,39,42$, $48-50,52)$. They have used protocols varying in the dose, number, and time of HCG injections as well as in the time of blood sampling for determination of plasma testosterone levels. Therefore, it is not possible to compare testosterone levels observed at the end of HCG tests between studies. Moreover, except for one report (51) of the daily excretion of testosterone following one IM injection of $5000 \mathrm{IU} / \mathrm{m}^{2}$ of $\mathrm{HCG}$, no study of the dynamics of response of plasma testosterone to single or repeated HCG stimulations in children is available in the literature.

On the other hand, it has been shown recently that in adult rats (45) as well as in men $(12,38)$, a single injection of $\mathrm{HCG}$ at respective doses of 40 to 2000 and $90 \pm 8 \mathrm{IU} / \mathrm{kg}$ of body weight after an initial acute stimulation of plasma testosterone induces a temporary state of steroidogenic unresponsiveness to further $\mathrm{HCG}$ stimulation. This phenomenon appears to be time- and dosedependent $(40,46)$ and is also observed in the immature rat $(43)$.

The present study had several purposes: first, to document the sequence of the changes in plasma levels of testosterone in response to one or repeated HCG stimulations during childhood, second, to investigate whether or not HCG induces a steroidogenic desensitization of the Leydig cell in children, and finally, to try to establish a rational protocol for HCG stimulation test in both prepubertal and pubertal boys.

\section{PATIENTS AND METHODS}

\section{SUBJECTS AND PROTOCOLS}

Eleven children were studied. Their ages, body surface areas, pubertal stages, and the protocols used for each subject are listed in Table 1. Subjects $1,4,6,7,9,10$, and 11 were unilateral cryptorchid boys who were otherwise normal. Subject 2 had simple hypospadias, and subjects 3 and 5 presented with male pseudohermaphroditism but had apparently normal testicular biosynthesis and other normal endocrine functions, as evidenced by studies made 1 to 2 and 8 to 9 years before the present one. Subject 8 was referred for small testis and genitalia for age. At the time of study. subjects 5 and 8 were at the early stage $(P$.$) of$ pubertal development as indicated by enlarged testicular volume and increased basal testosterone levels as compared to those of prepubertal boys. Test of testicular function was requested by the children's physicians in all cases and performed with the informed consent of the parents.

Testicular response to HCG was studied under three different protocols using the same batch of HCG (Pregnyl; Organon). In protocol I, at 8 AM, subjects received an IM injection of 1500 IU $(82 \pm 22 \mathrm{IU} / \mathrm{kg})$ of $\mathrm{HCG}$ which was repeated seven times at $48-\mathrm{hr}$ intervals. Blood was obtained before the first $\mathrm{HCG}$ injection and $4 \mathrm{hr}$ after each HCG injection, except for subject 5 in whom blood was collected before and $4 \mathrm{hr}$ after each HCG injection. In protocol II, at $8 \mathrm{AM}$, subjects were given two (IM or IV) injections of 1050 to $2000 \mathrm{IU}$ of $\mathrm{HCG}(83.5 \pm 33.5 \mathrm{IU} / \mathrm{kg})$ at $24-\mathrm{hr}$ intervals. Blood was drawn before, and 2,4 , and $8 \mathrm{hr}$ after each injection. 


\begin{tabular}{|c|c|c|c|c|c|c|c|}
\hline \multirow[b]{2}{*}{ Subject } & \multirow[b]{2}{*}{ Diagnosis ${ }^{2}$} & \multirow[b]{2}{*}{$\begin{array}{l}\text { Age } \\
(\mathrm{yr})\end{array}$} & \multicolumn{2}{|c|}{ Table 1. Subjects and protocols } & \multirow{2}{*}{ Protocol } & \multicolumn{2}{|c|}{$\mathrm{HCG}$} \\
\hline & & & $\begin{array}{c}\text { Body } \\
\text { surface } \\
\text { area } \\
\end{array}$ & $\begin{array}{c}\text { Pubertal } \\
\text { stage' }^{\prime}\end{array}$ & & $\begin{array}{l}\text { Dose per } \\
\text { injection } \\
\text { (IU) }\end{array}$ & Route \\
\hline 1 & $\mathrm{U} \mathrm{C}^{\cdot-2}$ & $3^{x_{12}}$ & 0.605 & 1 & I & 1500 & $1 \mathrm{M}$ \\
\hline 2 & $\mathrm{H}$ & $4^{\prime \prime 1} 12$ & 0.6 & 1 & I & 1500 & IM \\
\hline 3 & MPH & $5^{4} 12$ & 0.76 & 1 & 1 & 1500 & $\mathrm{IM}$ \\
\hline 4 & UC & $9^{1112} 12$ & 0.88 & 1 & I & 1500 & $\mathrm{IM}$ \\
\hline 5 & MPH & $1111_{12}$ & 0.98 & 2 & I & 1500 & $\mathrm{IM}$ \\
\hline 6 & UC & $1^{1 / 2}$ & 0.435 & 1 & II & 1050 & IV \\
\hline 7 & UC & $11 \%$ & 0.805 & 1 & II & 2000 & IV \\
\hline 8 & SG; & $12^{1 / 12}$ & 1.14 & 2 & II & 1500 & $1 \mathrm{M}$ \\
\hline 9 & UC & $1^{\prime \prime} 12$ & 0.42 & 1 & III & 1500 & IM \\
\hline 10 & UC & $37: 2$ & 0.61 & 1 & III & 1500 & $\mathrm{IM}$ \\
\hline 11 & UC & $4^{\prime \prime} 12$ & 0.6 & 1 & III & 1500 & $\mathrm{IM}$ \\
\hline
\end{tabular}

¿ UC, unilateral cryptorchidism; H. hypospadias: MPH, male pseudohermaphroditism; SG, small genitalia.

and then every morning at $8 \mathrm{AM}$ for seven days. Subjects studied with protocol III received $1500 \mathrm{IU}$ of HCG $(99 \pm 5 \mathrm{I} \mathrm{IU/kg})$ IM on days $0,5,10$, and 15 . Blood was sampled before, and 2, 4, and $8 \mathrm{hr}$ after each injection.

\section{METHODS}

Plasma testosterone $(T)$ was measured in triplicate by a specific radioimmunoassay after purification by celite chromatography as previously described (9). To minimize interassay variations, all samples from a single subject were run in the same assay. Blanks were negligible; sensitivity of the assay was $7.5 \mathrm{pg}$. Intraassay and interassay variations were 5.7 and $9 \%$, respectively.

Plasma HCG levels were measured by radioimmunoassay (28) in a single series. The reagents were purchased from CEA (Gifsur-Yvette, France). The sensitivity of the assay was 0.75 to 1 $\mathrm{mIU} / \mathrm{ml}$

Statistical analysis of the results (given in the text as mean \pm S.D.) was done using both paired and unpaired Student's $t$ test

\section{RESULTS}

PROTOCOL 1

Testosterone Levels. Mean basal plasma $\mathrm{T}$ levels in the 4 prepubertal boys were $0.079 \pm 0.038 \mathrm{ng} / \mathrm{ml}$, similar to values established in normal children (9). Plasma $T$ concentrations seen in subjects 2 and 4 at the end of the test ( 3.4 and $4.8 \mathrm{ng} / \mathrm{ml}$ ) were in the range of the response previously observed in 2 groups of normal boys submitted to the same test, i.e., $5.5 \pm 1.2$ (37) and 6.1 $\pm 1.4 \mathrm{ng} / \mathrm{ml}$, (10), respectively. In the two other boys, end-test values $(2.2$ and $2.5 \mathrm{ng} / \mathrm{ml})$ were comprised between 2 and 3 standard deviations below the mean normal response. Nevertheless, the pattern of the plasma $T$ response to repeated HCG stimulations had a similar profile in all subjects, an apparent progressive increase throughout the test (Fig. I, bottom).

In the pubertal boy (subject 5), after the first $\mathrm{HCH}$ injection plasma $T$ rose in $4 \mathrm{hr}$ by $2-$ to 7 -fold more sharply than in prepubertal boys (Fig. 1) and continued to rise until the $48 \mathrm{th} \mathrm{hr}$, being at that time in the range of basal adult $T$ levels (Table 2). The early responses (as defined by the changes in plasma $T$ seen $4 \mathrm{hr}$ after $\mathrm{HCG}$ injection) to repeated stimulations were also studied. Values observed before each HCG injection did not vary significantly after the second injection. The early responses to subsequent HCG injections varied: $T$ levels decreased somewhat within the $4 \mathrm{hr}$ following the second, third, fifth, and sixth injections, whereas a small rise was observed after the fourth and seventh injections (Table 3 ). Thus, T levels observed $4 \mathrm{hr}$ after each $\mathrm{HCG}$ injection decreased somewhat after the fourth $\mathrm{HCG}$ injection, but reincreased on day 13 (Fig. 1).

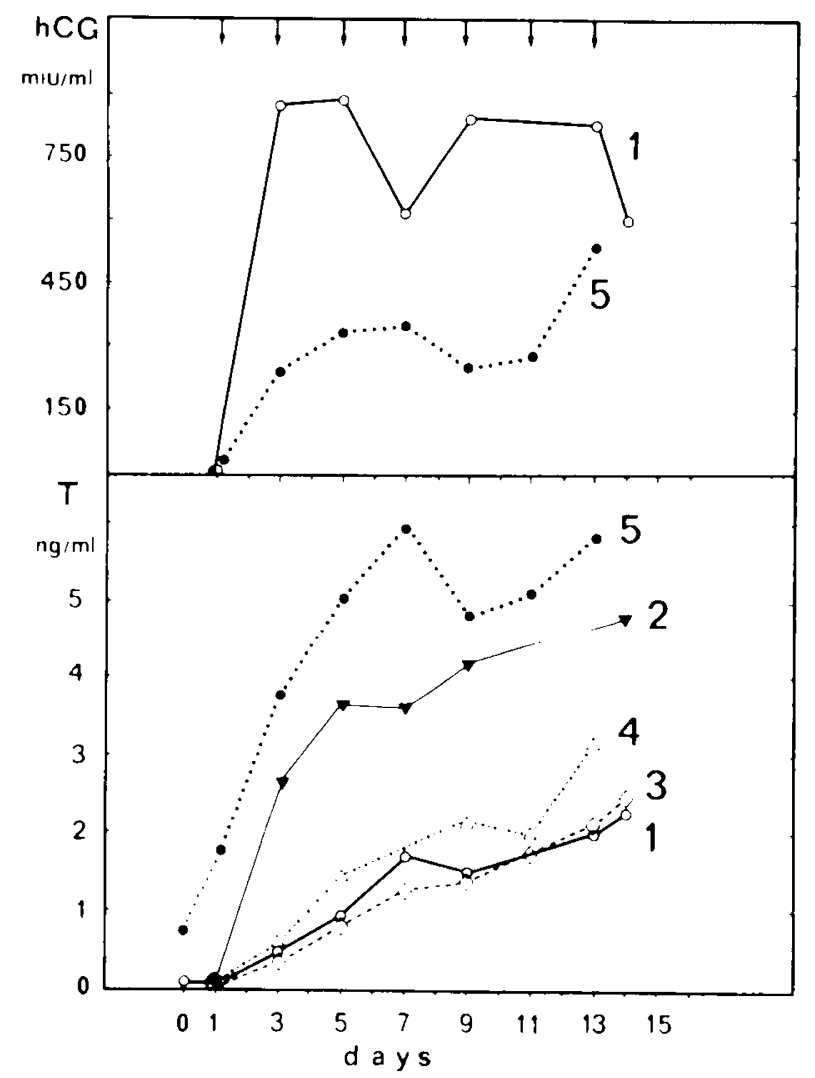

Fig. 1. Effect of repeated gonadotrophic stimulation (1500 IU IM every other day for seven days) on the plasma levels of HCG (top) and T (hottom) measured before the test (day $(0)$ and $4 \mathrm{hr}$ following each injection of HCG (arrows) (days 1 through 14).

The Plasma Concentrations of HCG. Plasma concentrations of HCG increased rapidly after the first injection of the hormone; $\mathrm{HCG}$ levels observed $4 \mathrm{hr}$ after any of the further HCG injections reached values comparable in each subject (Fig. 1; top) and were not correlated to the amplitude of the $T$ response.

\section{PROTOCOL II}

Prepubertal Boys (Subjects 6 and 7). Following the first HCG injection (whether administered IM or IV), testosterone levels were unchanged for the first $8 \mathrm{hr}$ in the 2 prepubertal boys studied. As illustrated in Figure 2, HCG levels increased sharply within 2 hr and then declined rapidly in subject 7 to whom HCG was 
administered IV. Meanwhile. T levels only began to rise slowly. Values observed at $24 \mathrm{hr}$ were significantly higher than basal levels but remained rather low (Table 4 ).

After the second HCG injection. T levels increased within $4 \mathrm{hr}$ by 2 -fold $(P<0.05)$ and continued to rise thereafter. Maximal

Table 2. Time course of the effect of a single injection of $H C G$ on the plasma levels of $T(\mathrm{ng} / \mathrm{ml})$ in two pubertal bols and in adult men

\begin{tabular}{cccc} 
Hrafter & \multicolumn{2}{c}{ Pubertal' } & \\
HCG & Subject 5 & Subject 8 & Adult \\
0 & 0.67 & 0.81 & $6.1 \pm 1.3^{2}$ \\
$4-8$ & 1.77 & 1.16 & $9.9 \pm 2.2^{4}$ \\
24 & & 2.37 & $8.0 \pm 1.6^{4}$ \\
48 & 4.38 & & $12.3 \pm 2.6^{4}$ \\
120 & & &
\end{tabular}

' Subject number at stage $P_{2}$ of Tanner (44)

2 Values obtained in 13 normal adult men. From Saez and Forest (38).

${ }^{3}$ Mean \pm S. 1 )

' $P<0 .(0) 1$ versus hasal

$P<0.001$ versus preceding line

Table 3. Plasma testosterone levels $(\mathrm{ng} / \mathrm{ml})$ before and $4 \mathrm{hr}$ after each of seven $H C G$ injections given at $4.8-h r$ intervals in a pubertal boy

\begin{tabular}{lccccccc} 
& & \multicolumn{9}{c}{ No. of injections } & & - \\
& 1 & 2 & 3 & 4 & 5 & 6 & 7 \\
Before & 0.67 & 4.38 & 5.23 & 5.83 & 5.82 & 5.60 & 5.38 \\
Four hr after & 1.77 & 3.76 & 5.02 & 6.82 & 4.79 & 5.06 & 6.14 \\
\hline
\end{tabular}

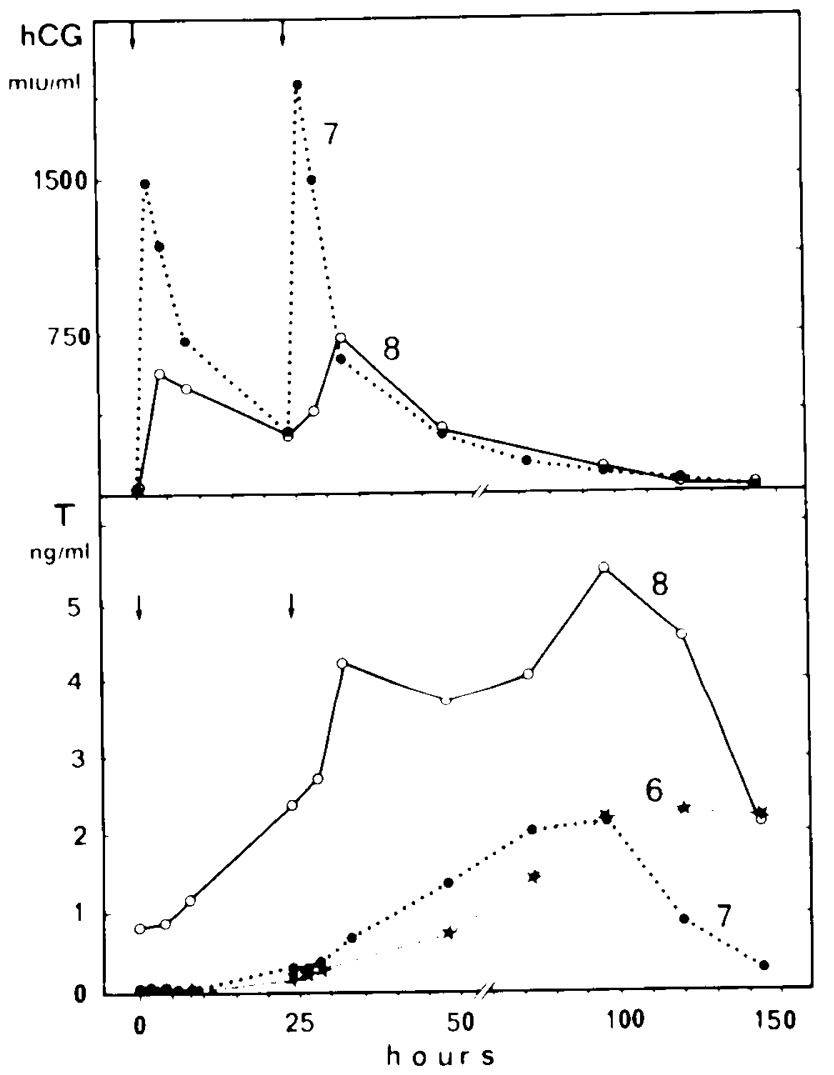

Fig. 2. Effect of 2 injections of -100$) \mathrm{lU} / \mathrm{kg}$ of $\mathrm{HCG}$ given at $24-\mathrm{hr}$ intervals on the sequence of the changes in plasma concentrations of $\mathrm{HCC} ;$ $(t o p)$ and testosterone $($ bottom). T levels in subject $6(\star)$. HC $(;$ and T were both measured in subjects $7(0)$ and $8(0)$.
Table 4. Time course of the effect of a single injection of $\mathrm{HCG}$ on plasma T levels in prepubertal children

$\begin{array}{cccc}\text { Hrafter } & & & \\ \text { HCG } & \text { Protocol } & n^{\prime} & \mathrm{T}(\mathrm{ng} / \mathrm{ml}) \\ 0 & \text { 1. II. III } & 9 & 0.07 \pm 0.033^{2} \\ 4-8 & \text { II III } & 5 & 0.09 \pm 0.144 \\ 24 & 11 & 2 & (0.14-0.31)^{\circ} \\ 120 & 111 & 3 & 2.58 \pm 0.31^{4}\end{array}$

n. number of subjects

Mean \pm S. D

Single values.

${ }^{1} P<0 .(0) \mid$ versus basal.

$P<0 .(0) 1$ versus $24 \mathrm{hr}$

values were observed at $96 \mathrm{hr}$. plateauing or declining until 144 hr. The late rise in plasma $T$ occurred at the time when plasma HC $(j$ levels were considerably reduced (Fig. 2). In subject 7. disappearance of HCG from plasma had at least 2 slopes with half-lives of 5 and $24 \mathrm{hr}$, respectively. These values are similar to those reported in adults (33).

Pubertal Boy (Subject 8). In the pubertal boy (subjest 8). the pattern was quite different: following the first HCG injection. the increase in plasma $T$ occurred earlier and was greater than in prepubertal boys (Fig. 2). After the second HCG injection. Talso increased within 8 hr by about 2 -fold. reaching levels almost 10 times higher than those seen in the youngest boys, but it decreased thereafter. Plasma $T$ reincreased again. and a second and larger peak was observed at $96 \mathrm{hr}$ at the time when maximal $\mathrm{T}$ values were also seen in the youngest boys.

Finally, the pattern in plasma $\mathrm{T}$ and the absolute $\mathrm{T}$ levels seen in this subject after 1 and 2 HCG injections resembled that observed in subject 5 , who, however. received the first two HCC; injections at 48 -hr intervals (Figs. 1 and 2).

The sequence of the changes in plasma HCG levels in subject 8 (Fig. 2. top) had an overall pattern similar to that of the prepubertal boy (subject 7 ) except that $T$ peak levels were 3 times lower and that their disappearance from plasma was slower (halflife of about $31 \mathrm{hr}$ ). These differences are likely related to the mode of administration. $I M$ injection, resulting in a slow release of $\mathrm{HCG}$ into the circulation.

\section{PROTOC (O). 111}

Testosterone Levels. The plasma concentrations of $\mathrm{T}$ found before and 4 to $8 \mathrm{hr}$ after the first $\mathrm{HCC}$ injection in subjects 9 to 11 were not different from those observed at the same times in subjects submitted to protocol II. Values were therefore pooled and are given in Table 3. Likewise. T levels $(2.58 \pm 0.31 \mathrm{ng} / \mathrm{ml})$ found in this protocol $120 \mathrm{hr}$ after the first $\mathrm{HCG}$ injection were similar to those $(2.15 \pm 0.03 \mathrm{ng} / \mathrm{ml})$ obtained at the same time but after 2 injections of HCG in protocol II (Table 5 ).

On day 5 , after the second $\mathrm{HCG}$ injection, plasma $\mathrm{T}$ increased significantly $(P<0.05)$ within 4 hr by $1.4 \pm 0.12$-fold (Fig. 3$)$. In contrast. on day 10 , T levels did not vary significantly during the $x$ hr following the third HCF injection. Furthermore, the "late" post-HCG rise apparently did not occur or did not occur at the same time because the levels of $\mathrm{T}$ observed $120 \mathrm{hr}$ after the third HCG injection $(4.97 \pm 2.17 \mathrm{ng} / \mathrm{ml})$ were not significantly different from those $(4.6 \pm 1.6)$ observed $120 \mathrm{hr}$ after the second injection (Table 4: Fig. 3. open columns on days 15 and 10 ).

On the other hand, on day 15 , an acute and significant $(P<$ $0.05) \mathrm{T}$ response to the fourth HCG injection was observed within $8 \mathrm{hr}(1.4 \pm 0.05$-fold increase). Mean $\mathrm{T}$ levels $(6.5 \pm 1.4 \mathrm{ng} / \mathrm{ml}$ observed at that time were identical to those observed after 7 HCG injections (protocol $\mathrm{I}$ ) in normal boys $(6.1 \pm 1.4 \mathrm{ng} / \mathrm{ml}$ ) using the same radioimmunoassay technique $(10)$. Both end-test values are those of adult men in basal conditions (9).

HCG Plasma Levels. They were measured in 2 subjects (Fig. 3. top). Values observed before or after each HCG injection were similar in each subject but varied between subjects, as previously 
Table 5. Effect of repetition of HCG injections at 1-, 2-, or 5-day intervals on the plasma concentration of $T$ in prepubertal bols

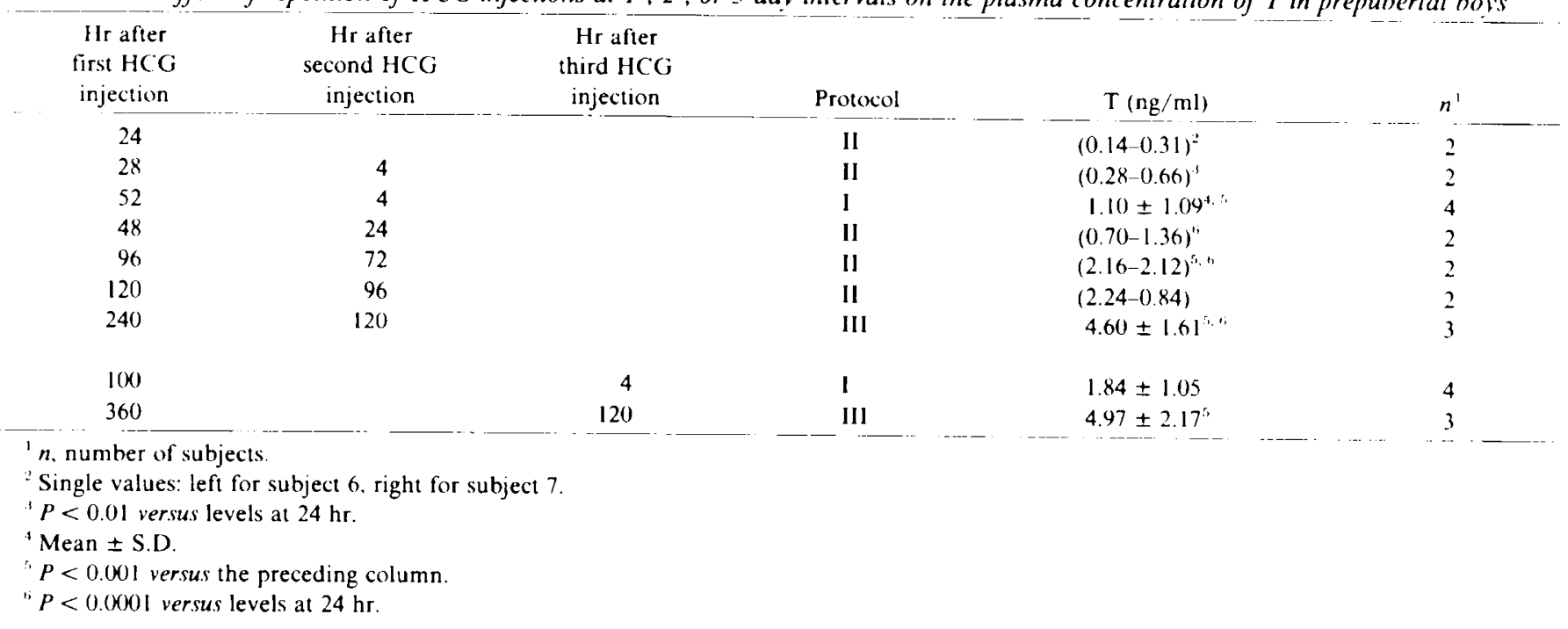

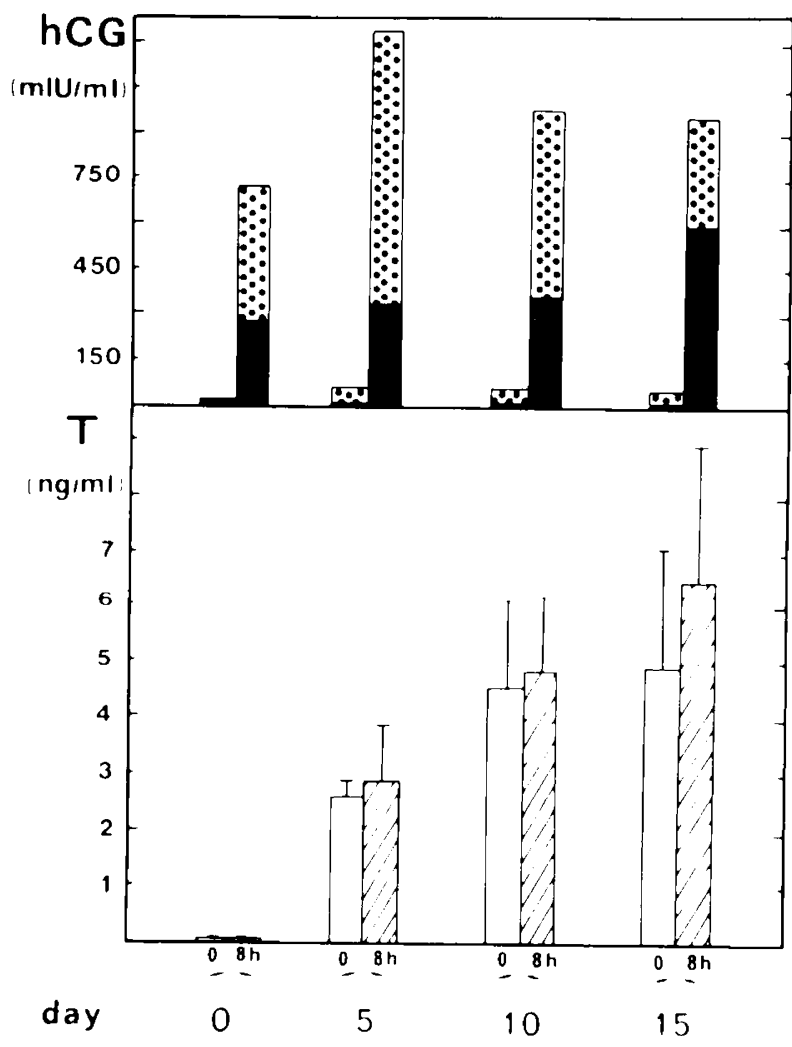

Fig. 3. Effect of four injections of HCG $(\sim 100 \mathrm{IU} / \mathrm{kg})$ given at 5 -day intervals on the plasma levels of testosterone of subjects 9 to 11 (bottom). Mean \pm S.D. of values obtained before (open columns) and $8 \mathrm{hr}$ after (hatched columns) each HCG injection. Top, corresponding plasma levels of HCG observed before and $8 \mathrm{hr}$ after each HCG injection in subjects 9 (dotted columns) and 10 (black columns).

observed in protocol I. They obviously did not correlate with the testosterone responses (Fig. 3).

\section{DISCUSSION}

This study has obvious limitations regarding the number of subjects studied and the frequency of the blood sampling which was restricted to a reasonable number for ethical considerations. However, because this study was focused on the dynamic of the $\mathrm{T}$ response to $\mathrm{HCG}$, some conclusions can be drawn.
Whatever the protocol used, it is obvious that there was no correlation between the plasma levels of HCG and T. This was more apparent in protocol II (Fig. 2); maximal plasma levels of $\mathrm{T}$ were observed when those of $\mathrm{HCG}$ were decreasing. Using dosages of HCG comparable to most protocols currently used, the HCG concentrations reached in plasma are enormous and even $100 \mathrm{hr}$ later still are far higher than any physiologic levels of luteinizing hormone ( $\mathrm{LH}$ ) seen in normal adults (assuming a potency ratio of 2:1 between $\mathrm{HCG}$ and $\mathrm{LH}$ ). Thus, during most of the period studied, the Leydig cells are exposed to very high concentrations of gonadotrophin. However, if testicular stimulation only depends upon the circulating levels of HCG, there would have been a sharp increase in plasma $T$ after each $H C G$ injection. It was not the case (Fig. 3: Table 3).

The $\mathrm{T}$ response to HCG appeared to be rather related to the time elapsed either after the initial stimulation or between two stimulations because maximal $T$ responses were observed 72 to $120 \mathrm{hr}$ after either one or two HCG stimulations (Figs. 2 and 3 ). Furthermore, the $T$ values observed after the second or third $\mathrm{HCG}$ injection administered at 5-day intervals (protocol III) were in the range of those previously observed in normal boys given seven injections every other day $(10,37)$.

In adult rat, an HCG refractoriness of the Leydig cell steroidogenesis has been described. This is a complex phenomenon (see reviews, Refs. 18 and 45 ). It is reflected by the time course of the $T$ response to $H C G$, i.e., after one $H C G$ injection. plasma $T$ rises sharply (early response) and then declines. A spontaneous and paradoxical peak of $\mathrm{T}$ (late response) is observed 50 to $100 \mathrm{hr}$ later. A second injection of $\mathrm{HCG}$ is uneffective in modifying $\mathrm{T}$ levels for approximately 3 to 5 days. A quite similar pattern of $T$ response to HCG has been recently described in adult men (Table 2: Refs. 12 and 38 ).

In the prepubertal subjects hereby studied, although the late paradoxical rise (protocols II and III) occurred at about the same time ( 72 to $120 \mathrm{hr}$ ) as in adult men studied with the same protocol conditions ( $\mathrm{HCG}$ dose/ $\mathrm{kg}$ body weight and rhythms of injections). the early $T$ response to $\mathrm{HCG}$ differed. Thus, if the $\mathrm{HCG}$-induced steroidogenic refractoriness of the Leydig cells occurs in children. it is not apparent for at least the first $24 \mathrm{hr}$ following $\mathrm{HCG}$ stimulation. Between children and adults, there are obvious differences of testicular steroid production, endogenous LH levels. and Leydig cell maturation. The HCG-induced Leydig cell desensitization also occurs in immature rat (43) or in animals deprived of endogenous LH (19). In hypophysectomized rats, early $T$ response to $\mathrm{HCG}$ is blunted, whereas the delayed peak is seen at about the same time as in intact animals (19). This pattern strikingly resembles that observed in prepubertal children (protocol II). 
On the other hand, besides its acute effect on steroid biosynthesis. HC C has "trophic" effects on the Leydig cell itself, inducing protein synthesis, histologic changes. and enzyme activities (17. 41). Enzyme induction seems to be a slow process requiring about $48 \mathrm{hr}$ before it is expressed $(17,20)$. It is possible that this longterm effect on the enzyme activities of the testicular steroidogenic pathway may account for the late T response to $\mathrm{HCG}$. The fact that in all protocols used there was a progressive rise in $T$ levels would at first support this view. However, the profiles of the $T$ response observed in the two pubertal boys and the slight decrease in T levels $4 \mathrm{hr}$ after 4 subsequent HCG injections in subject 8 or the blunted early response observed on day 10 in prepubertal boys submitted to protocol III cannot then be fully understood.

It is possible that in prepubertal children as in the rat. high doses of $\mathrm{HCG}$ might induce a steroidogenic desensitization phenomenon parallel to its trophic effect, the latter being responsible for increasing testosterone production at the time of recovery from desensitization. This hypothesis remains however to be demonstrated.

Whatever the exact mechanism responsible for the patterns of the $T$ response to $\mathrm{HCG}$ stimulation. our results give some basis for the use of a more rational HCG stimulation test. Various protocols are currently in use. They all vary in the dosage of each $\mathrm{HC}^{\circ} \mathrm{C}$ injection (500) to $\left.5000 \mathrm{IU}\right)$, the number ( 1 to 7 ), and the rhythm (lor 2-day intervals) of the injections. Moreover, in most instances, the single blood sampling made after the last HCG injection is not rigourously timed. Each of these parameters has its own or mutual importance.

From the present results and data obtained in the rat $(17,20)$. it appears evident that daily injections of $\mathrm{HCG}$ are not necessary because basal $T$ levels are increased by almost 30 - to 50 -fold the fifth day after a single injection. That the HCG-induced steroidogenic refractoriness recovers in children after the same lapse of time as in rats (after 3 days) (18) remains to be established, but it is suggested by the profiles of plasma $T$ after $\mathrm{HCG}$. If so, an earlier repetition of HCG stimulation is useless and might even be harmful $(26.51)$ with plasma concentrations of $\mathrm{HCG}$ reaching huge and unphysiologic levels after each injection.

Should even HCG stimulation be repeated? Some of the protocols in current use $(1,3,37)$ led to an increase in plasma $T$ levels to the range of adult basal values. Are those absolute criteria? In testing testicular response to $\mathrm{HCG}$, the major needs are to evidence Leydig cell endocrine function and to recognize pathologic conditions. As clearly pointed out by Zachman (51) who several years ago has proposed a single dose HCG stimulation test. attainment of adult $T$ levels might not be a preemptory criterion because full maturation of interstitial tissue does not seem to be achieved prior to the occurrence of a steroidogenic testicular response to HCG

On the other hand, there are pathologic conditions such as hypopituitarism $(4,15,30,32)$ or hypogonadotrophic hypogonadism $(4,15,30)$, abnormal testicular biosynthesis or dysgenetic testis $(14,29,35,39)$ in which substantial increase in plasma $T$ levels may require prolonged HCG stimulation. Cryptorchidism $(2.6 .8,11.31,48)$ is another situation in which HCG is used both for investigation of normal testicular endocrine capacity $(20)$ and for therapeutic purpose $(3,8,10)$. Prolonged HCG stimulation seems to be required for positive effects, whether or not the hormone acts directly or indirectly by a still unknown mechanism (16, 21). Therefore. repetitions of HCG stimulations might nevertheless be necessary.

Which dose should be used? There are no data yet to answer this question. In vitro production of $\mathrm{T}$ by testes from rats given injections of 10 or $100 \mathrm{IU}$ of HCG (about 50 to $500 \mathrm{IU} / \mathrm{kg}$ ) seems to be impaired to the same extent during the refractoriness period However, both steroidogenic response and steroidogenic desensitization of the Leydig cell are dose related $(40,46)$. Which predominates over which and at which times is totally unknown in the human. Because HCG would appear to affect both sensitivity and responsiveness in the immature rat testis (43), it seems mandatory to use a constant dose for body size (per $\mathrm{kg}$. for instance) in a given protocol, which is not by far a current general use.
From previous data in adults (38) and as suggested by the results obtained in children submitted to protocols II and III. the mode of injection of $\mathrm{HCG}$ does not seem to influence the pattern of the T response to $\mathrm{HCG}$.

Finally, almost all authors have favored the easiest sampling of blood over urine collection and used plasma $T$ to estimate testosterone secretion. As is clearly shown in this preliminary study. timing of blood sampling after the last $\mathrm{HCG}$ injection is most important. When carefully reinvestigated, it might improve the homogenity so often looked for (see review in Ref. 10) of the results obtained with a given protocol.

In conclusion, from our results and the above-mentioned data in the rat, in children we propose an HCG stimulation test consisting of 2 to $4 \mathrm{HCG}$ injections at a body size-related dosage (50) to $100 \mathrm{IU} / \mathrm{kg}$ body weight) administered at 4-day intervals. Blood should be samples before the test and 4 to 6 and $72 \mathrm{hr}$ after the last injection. It is, however, evident that standardization of this stimulation test will greatly benefit from careful evaluation of optimal dose and times of administration of the hormone and of the blood sampling.

\section{RIFEREN(ES AND NOTIS}

1. Anderson, 1). ('. Marshall. J. ( .. Young, J. L... and Fraser, T. R.: Stimulation tests of pituitary Leydig-cell tunction in normal male subjects and hypogonadal men. (Cin. Endocrinol. $l: 140$ (1972)

2. Attanasio. A. Jendericke. K.. Bierich. J. R.. and Gupta. D.: (linical and hormonal effects of human chorionic gonadotrophin in prepubertal cryptorchid boys. J. Endocrinol. 0.3. 50) (1974).

3. Altanasio. A. Rager. K.. and (jupta. D.: Plasma testosterone in prepubertal croptorchid bovs under long term therapy. Horm. Res. (Basel), ?:77 (1976)

4. Bardin. (. W. Ross, (;. T. Ritkind. A. B. Cargille. C. M.. and Lipsett. M. B Studies of the pituitary-leydig cell axis in young men with hypogonadotophic hypogonadism and hypoosmia: comparison with normal men. prepubertal boys and hypopituitary patients. J. (lin. Invest. 48: $2(146$ (1964)

5. Cacciari. B. Cicognani. A.. Tassoni. P.. Flamigni, P.. Bolelli. F.. Pirazsoli. P., and Salardi, S.: Plasma testosterone and estradiol concentration in prepubertal boys with cryptorchidism hefore and after dexamethasone and after humat chorionic genadotropin administration. Hels. Paediatr. Acta. 24: $27(1974)$.

6. Cacciari. 1.. Cicognani. A.. Pirazzoli. P.. Zappulla. F.. Tasson., P.. Bernardi. F. and Salardi. S.: Hypophyso-gonadal function in the cryptorchid child: differ ences between uniateral and hilateral cryporchids. Acta Endocrinol.. k.3. 1 K2 $(1976)$.

7. Folk. R. I... Taylor. J. N. Sotos. J. F.. Vorys. N. and Wieland. R. (i.. Fffect of chorionic gonadotropin on urinary testosterone and 17 -ketosteroids in prepuhertal males and males with spermatic maturation arrest. Am. J. Med. Sui. $255: 221(1968)$

s. Foresc. M. ( $($.. Plasma steroid hormones in prepubertal crypturchid boys in basal statc and after long term gonadotropin stimulation. In: J. R. Bierich. K. Rager. M. B. Ranke: Maldescensus testis. p. 69 (Urhan Schwazenherg. Munich. Wein. Baltimure. 1977

4. Forest. M. ( levels in the newborn and in normal and hypogonadal children: use of a sensitive radiommunoassay for testosterone. J. ( Clin Fndocrinol. Metah. in: $1132(1973)$.

10. Forest. M ( $;.$ Saez. J. M.. and Bertrand. J.: Assessment of gonadal function in children. Paediatrician, 2: 102 (197.3).

11. Forest. M. (;.. Saez, J. M.. Sann. L.. and Bertrand. J.: La fonction gonadique che/ le nourisson et l'enfant. Arch. Fr. Pediatr.. 11: 587 (1974).

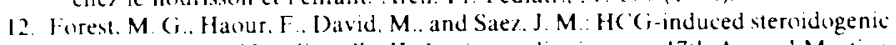
refractoriness of Levdig cells. 11. In vivo studies in men. 17 th Annual Meeting of the European Soxiety for Paediatric Endocrinology. Athens. September 10 13. $197 x$.

13. Frasier. S. D). and Horton, $R .:$ Androgens in the peripheral plasma of prepubertal childicol and adults. Stcionds. $4.777(1 \%$ (\%)

14. (irant. I). B.. Laurance. B. M. Atherden. S. M... and Ryness. J.: HC (; stimulation test in children with abnormal sexual development. Arch. Dis. (hild.. 51: 596 (1976).

15. Haber. A.. Dray, F.. Josso, N.. Cachin. O., and Rappaport, R.: Variations de la testosterone plasmatique apres stimulation par la gonadotrophine chorionique (HC (;) chez les garçons atteints d'insuffisance hypothalamo-hypophysaire. Ann. Endocrinol., 3. 534 (1972).

16. Hadriselimovic. I.. Girard, J., and Herzog. B.: Treatment of cryptorchidism by synthetic luteinizing hormone-releasing hormone. Lancet. $2:$ i1 25 (1477).

17. Hail. P. F.: (Gonadotropin regulation of testicular function. In: K. B. Lik-Nes: The androgens of the testis. p. 73 (Marcel Dekker. New York, 1470).

18. Haour, F. and Saez. J. M.: Leydig cell responsiveness to LH-HC ( i stimulation: mechanisms of $\mathrm{HC}(j-$ and steroid induced refractoriness. In: $K$. W. McKerns: Structure and function of the gonadotropins. p. 497 (Plenum Press, New York. 197i).

19. Haour. F.. Sanchez, P., Cathiard. A. M.. and Saez. J. M.: Gonadotropin receptor regulation in hypophysectomized rat Leydig cells. Biochem. Biophys. Res. (ommun.. \&1: 547 (1978). 
20. Hesse. V., Stal, F., and Kleinteic. B.: Testosterone reserve capacity of infantile and juvenile testes after operative correction of testicular maldescencens. Endokrinologie, 09 : 28 (1977).

21. Job. J. C.. Gendrel, D., Safar. A., Roger. M., and Chaussain. J. L.: Pituitary LH and FSH and testosterone secretion in infants with undescended testes. Acta Endocrinol., 85: 644 (1977).

22. Knorr, D.: Uber die Ausscheidung von freiem und glucuronsäuregebunde nem Testosteron im Kindes und Reifungsalter. Acta Endocrinol. 54: 215 (1967).

23. Leach. R. B.. Maddock. W. O.. Tokuyama. I.. Paulsen. C. A., and Nelson, W. O. (linical studies of testicular hormone production. Recent Prog. Horm. Res.. 2 377 (1956).

24. Lipsell, M. B., Wilson, H., Kirchner. M. A., Korenman, S. G.. Fishman, C. M Sarfaty. G. A., and Bardin. C. W.: Studies on Leydig cell physiology and pathology: secretion and metabolism of testosterone. Recent Prog. Horm. Res.. 22: 245 (1966)

25. Loras, B., Ollagnon, C., and Bertrand, J.: Dosage de la testosterone urinaite chez. le garçon normal durant la seconde enfance et au cours de la puberte: action de la gonadotrophine chorionique. Pediatrie. 21: 455 (1966)

26. Maddock. W. O.. and Nelson. W. O.: The effect of chorionic gonadotropin in adult men: increased estrogen and 17-ketosteroid excretion, gynecomastia. Leydig cell stimulation and seminiferous tubule damage. J. (Clin. Endocrinol. Metah.. 12: 985 (1952)

27. Maurer. W.. Volkweim. U., and Tamm. J.: The effect of intravenously adminis tered human chorionic gonadotropin on plasma levels of testosterone and dihydrotestosterone in normal male subjects. Acta. Endocrinol., 72: 615 (1973).

28. Midgley, A. R.: Radioimmunoassay: a method for human chorionic gonadotropin and human luteinizing hormone. Endocrinology, 74: 10 (1960).

29. Neto, R. S., Rivarola, M. A., Coco, R., and Bergada. C.: The testis in patients with abnormalities of sex differentiation. Histology and endocrine function. Acta Endocrinol., 73: 179 (1973).

30. Perheentupa. J.. Dessypris. A.. and Adlercreutz. H.: Gonadotropin test of the functional capacity of the Leydig cells in normal and hypogonadal boys. Clin Endocrinol., I: 141 (1972).

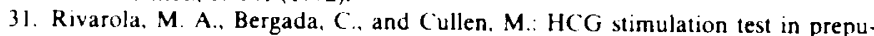
bertal boys with cryptorchidism. in bilateral anorchia and in male pseudohermaphroditism. J. Clin. Endocrinol. Metab., 3l: 526 (1970).

32. Rivarola, M. A.. Heinrich. J. J., Podesta. E. J., de (hwojnik. M. F.. and Bergada. (.: Testicular function in hypopituitarism. Pediatr. Res., 6: 634 (1972).

33. Rizkallat. T. Gurpide. E., and Vande Wiele. R. L.: Metabolism of HCG in man J. Clin. Endocrinol. Metab., 29: 92 (1969).

34. Rosenberg. E. R., Mancini. E., Crigler, J. F., and Bergada. C.: Effect of human menopausal gonadotropins on prepubertal testis. In: E. Rosenberg: Gonadotropins. p. 527 (Geronx Inc., Los Altos. 1968).

35. Rosenfield, R. L., Barmach de Niepomniszsze, A.. Kenny, F. M.. and Genel, M.: The response to human chorionic gonadotropin (HCG) administration in boys with and without $\Delta^{5}-3 / \beta$-hydroxysteroid dehydrogenase deficiency. J. Clin. Endocrinol. Metab.. 34: 370 (1974).

36. Rudd. B. T., Rayner. P. H. W., Smith, M. R.. Holder. G.. Givani, S. K. M., and Theodoris. C. G.: Effect of human chorionic gonadotrophin on plasma and urine testosterone in boys with delayed puberty. Arch. Dis. Child.. 48: 590 (1973).

37. Saez. J. M.. and Bertrand, J.: Studies on testicular function in children: plasma concentrations of testosterone, dehydroepiandrosterone and its sulfate before and after stimulation with human chorionic gonadotrophin. Steroids, 12: 749 (1968)

38. Saez, J. M., and Forest. M. (3.: Kinetics of human chorionic gonadotropin- induced steroidogenic response of human testis. I. Plasma testosterone. Implications for human chorionic gonadotropin stimulation test. J. Clin. Endocrinot. Metab. 44: $278(1978)$

39. Saez. J. M.. Frederich. A.. and Bertrand, J.: Endocrine and metabolic studies in children with male pseudohermaphroditism. J. (Clin. Endocrinol. Metab., 32. $611(1971)$

40. Saez, J. M., Haour, F., Tell, (j. E. P.. Gallet, D., and Sanchez, P.: Human chorionic gonadotropin induced Leydig cell refractoriness to gonadotropin stimulation. Mol. Pharmacol., 14: 114 l (1978).

41. Samuels. L. T., and Helmreich. M. L.: The influence of chorionic gonadotropin on the $3 / 3-0)$ deshydrogenase activity of testes and adrenals. Endocrinology. 5.8: 435 (1956)

42. Scholler. R.. Roger. M.. Leymarie, P., and Castanier, M.: Evaluation of Leydigcell function in normal prepubertal and pubertal boys. J. Steroid Biochem., 6 $95(1975)$.

43. Sharpe. R. M.: Gonadotrophin-induced reduction of the steroidogenic responsiveness of the immature rat testis. Biochem. Biophys. Res. Commun.. 76: 957 (1977).

44. Tanner, J. M.: In: Growth at Adolescence. Ed. 2. p. 32 (Blackwell Scientific Publishers, London, 1962).

45. Tell, (j. P.. Haour. F., and Saez, J. M.: Hormonal regulation of membrane receptors and cell responsiveness: a review. Metabolism, 27: 1566 (1978).

46. Tsuruhara. T.. Dufau, M. L., Cigorraga, S., and Catt. K. J.: Hormonal regulation of testicular luteinizing hormone receptors. Effects on cyclic AMP and testosterone responses in isolated Leydig cells. J. Biol. Chem., 252: 9002 (1977).

47. Vivanco, F.. Gonzales-Gancedo, P., and Ramos, F.: A simple clinical test for measuring the serum testosterone response to intravenous infusion of human chorionic gonadotropin. Acta Endocrinol.. 73: 790 (1973).

48. Walsh, P. C., Curry. N., Mills, R. C., and Siteri, P. K.: Plasma androgen response to HCG stimulation in prepubertal boys with hypospadias and cryptorchidism J. Clin. Endocrinol. Metab., 42: 52 (1976).

49. Weinstein. R. L., Kelch, R. P., and Jenner, M. R., Kaplan, S. L., and Grumbach. M. M.: Secretion of unconjugated androgens and estrogens by the normal and abnormal human testis before and after human chotionic gonadotropin. J. (Clin. Invest., 53: 1 (1974)

50. Winter, J. S. D.. Taraska, S.. and Faiman. (. The hormonal response to HCG stimulation in male children and adolescents. J. Clin. Endocrinol. Metab.. 34. 348 (1972)

51. Zachmann. M.: The evaluation of testicular endocrine function before and in puberty. Acta Endocrinol. Suppl., 70): 1 (1972).

52. Zachmann, M.: Evaluation of gonadal function in childhood and adolescence Helv. Paediatr. Acta Suppl.. 34: 53 (1974).

53. This study was presented in part at the XIIlth Meeting of the European Society for Paediatric Fndocrinology. Athens, September 6-9.1978.

54. The authors are deeply grateful to Dr. Jose M. Saez (INSERM U 162) for his constant interest and advice. His experimental studies in the rat and his communicative enthusiasm have greatly contributed to the initiation and realization of this work. The authors also wish to thank all staff members of the Pediatric Clinic for their assistance in collecting blood samples and Joelle Bois for her expert secretarial assistance.

55. Requests for reprints should be addressed to: Maguelone (j. Forest, M.D., Unite de Recherches et Metaboliques chez l'Efant. INSERM U 34 Hopital Debrousse, 29 Rue Sweur Bouvier, 69322 Lyon Cedex 1. France.

56. This research was supported by INSERM (grant ATP 33.76.65).

57. Received for publication April 30, 1979.

58. Accepted for publication August 13, 1979. 